\title{
The Living Colacanthid Fish from South Africa
}

\author{
By Dr. J. L. B. Smith, Rhodes University College, Grahamstown
}

$\mathrm{T}$ HE recent discovery of the Coelacanthid fish (Latimeria chalumnoe J. L. B. Smith) near East London, as described in NATURE of March 18, p. 455, has aroused great interest. This has partly found expression in numerous requests from all parts of the world for the earliest possible publication of a detailed description. I am able to pursue my investigations only in very limited spare time. The preparation of an adequately illustrated detailed description, under present conditions, will occupy several months. I have therefore decided upon the somewhat unusual procedure of issuing a synopsis of the more important results of my investigations to date. This is in the form of brief outlines without discussion.

Few scientific workers are as fortunate as those who have concentrated upon Coelacanthid remains. The present specimen is a living tribute to the accuracy of their interpretations and reconstructions.

The specimen was somewhat damaged in the trawl, the skin having been broken in several places. Repairs were skilfully executed by the taxidermist.

Skull and head. The skull is unfortunately not quite intact. The basisphenoid and part of the structures around the foramen magnum were removed (and discarded) in mounting. The soft parts of the head appear to have been removed rather roughly. The remaining tissues are in poor condition. Only the structures left intact will be described as fact.

Air-bladder. According to the fairly definite evidence of the taxidermist, this organ was at the very most but feebly ossified.

The scales are cycloid and but little ossified. The proportion of residue after ignition of the unornamented portion of a mid-body scale is very much less than, but qualitatively identical with, that obtained by similar treatment of a teleostean scale. The exposed surface of a scale varies from one fourth to one sixth of the total area. The ornamentation on the caudal scales is in the form of spines, on the rest of the body as tubercles. The tubercles are superficial only; each is set in a thin oval basal plate with corrugated surface. The plates are attached to the scales by tissue which is softened by alkali. The tubercles are of simple structure with a central cavity (see Fig. 1). The lateral line tubes are posteriorly widely bifurcate.
Fins. All the rays of the first dorsal, of the principal and of the supplementary caudal are spinate. A few of the rays of the second dorsal and of the anal are basally feebly spinate. The outer face of the pectoral is spinate. The pelvics only are quite smooth. The bony rays of the dorsal and caudal are articulated. The soft rays are finely articulated to their bases. All rays are composed of two fused lateral segments.

Dermal bones. The cheek-bones are a postorbital, a squamosal, a preopercular and a suborbital (lacrimojugal). On the middle of the lower surface of each cheek is a small bony stud which may be an obsolescent quadratojugal. The opercular is moderate in size. There are two dermal structures in a stage of arrested metamorphosis from scale to dermal bone, which are regarded as subopercular and interopercular respectively.

The intertemporals and the supratemporals appear to be fused. The exposed portion of each frontal is small, oval and flat. These bones are all feebly ornamented. The splenial and angular alone show externally on the lower jaw. The gulars are large and heavy.

Fronto-rostrals. Just beneath the skin there are nineteen bones in this series on each side. One large frontal and a smaller 'pre'-frontal; nine 'rostro-nasals', including a canal-bearing bone (No. 18) often named 'premaxilla' in fossils.

There are eight bones in the 'parafrontal' series, the anterior expanded bones having been named 'antorbitals' in fossils. Besides these nineteen there are the small dentigerous rostral plates. Most of these bones are small and laminate.

Sensory canals. The main canals run much as have been shown in reconstructions. From the lateral line the canal passes through the supratemporals and intertemporals, thence 'parafrontal' to the snout. There it has a small superior median branch. Just below that it gives off an inferior branch which is the infraorbital canal (running through the lateral limb of bone No. 18, which anastomoses with the suborbital). Below this junction is a commissure across the snout. The canal then runs downwards and curves outwards to end on the outer edge of the rostrum around the inner face of bone No. 18. Just behind the frontal is the junction of the infraorbital canal running downwards through the postorbital, which continues through the suborbital to the snout. The anterior limb of the squamosal anastomoses with the 


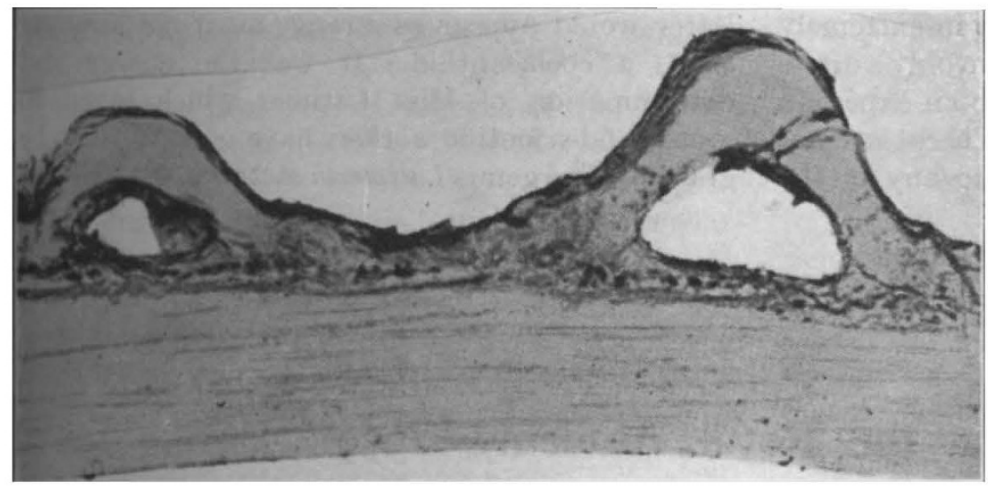

Fig. 1.

Section of A SCALE $(\times 50)$ of Latimeria chalumnoe J. L. B. SMITH. and typically coelacanthid. There is no hyomandibular. The prevomer is an unexpectedly solid structure, with the anterior edge of the autopalatine bearing against the hind surface of its outer columnar vertical process. The ectopterygoid overlaps the autopalatine and the pterygoid above.

Upper jaw. Maxillæ are absent, probably also premaxillæ. The upper jaw bears paired dermal plates attached to rostrals, prevomers, palatines and ectopterygoids. These plates are of fused postorbital-suborbital anastomosis and carries the jugal canal which continues through the preopercular, thence as a tube in the skin obliquely over the lower outer face of the quadrate. It enters the angular very obliquely and thence runs forward on the lower margin just below the surface to the symphysis. There is a posterior branch on the lower surface of the angular.

Olfactory organs. There are on each side three 'narial' apertures, two conventionally on the side of the snout before the eye, the third on the front of the rostrum. Each opening is the end of a simple tube which leads from a median capsule situated beneath a thin layer of mesethmoidal cartilage. The tubes and the capsule were apparently lined with fine rugose tissue. The capsule is depressed biconical in shape. There is also on each side of the rostrum an infero-lateral nasal tentacle, apparently imperforate. On each side of the snout, inferior and anterior to the median nasal cavity, lies a sac, typically covered below, laterally, and partly behind, by the prevomer, in front by bone No. 18. That bone lies against the outer surface of the hind column of the prevomer. These sacs correspond with the usual 'olfactory capsules', but do not appear to have any external narial opening. The nerve supply to these paired capsules appears to be from the olfactory lobe, and to enter at the upper inner portion of the surface. The nerve supply of the mesethmoidal (pineal ?) cavity appears to come from farther back.

Respiratory organs. The branchial arches and appendages were lost. The arches are stated to have been strongly spinate. Remaining is a spinate epihyal and ceratohyal. Also a superficially ossified tuberculate copula ('tongue'), to which appear to have been attached four branchial arches. There is apparently a hyoidean gill-slit behind the free margin of the 'preoperculum'. The spiracles are small and probably functionless.

The palato-pterygo-quadrate apparatus is massive small teeth, and each bears one or two large conical tusks. On the pterygoids and parasphenoid are conical granular teeth. There are two feeble granulate 'epi'-pterygoid areas.

Lower jaw. There is a series of small 'labial' dentate plates on the outer surface of the dentary. Superiorly are four dentate plates on each dentary. The anterior coronoid is small and bears granular teeth as well as several large tusks. The posterior coronoid is large and feebly granulate at the base. The articular-prearticular plate is very long and is granulate anteriorly only.

Several letters from overseas have contained very harsh criticism about the loss of the carcass of this fish. Few persons outside South Africa have any knowledge of our conditions. In the coastal belt only the South African Museum at Cape Town has a staff of scientific workers among whom is an ichthyologist. The other six small

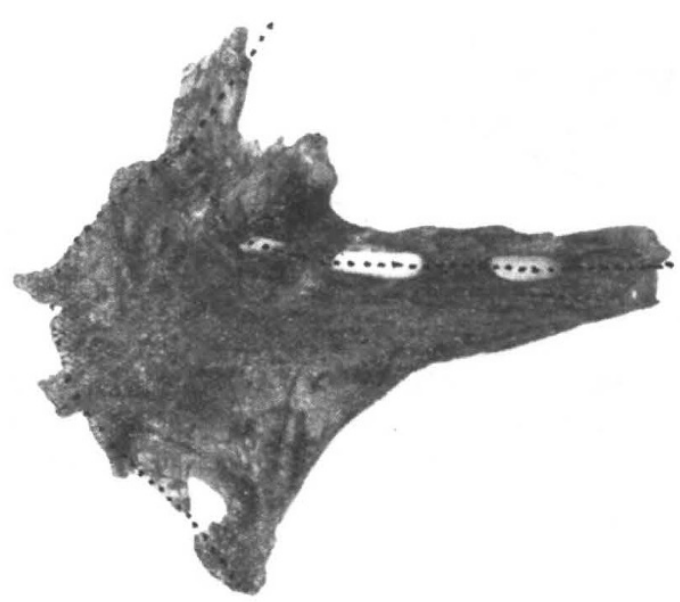

Fig. 2.

ROSTRO-NASAL, No. 18. NAT. SIZE. INNER MARGIN TO THE LEFT. A PIECE OF WHITE PAPER HAS BEEN INSERTED INTO THE CANAL. The DOTTED LINES SHOW THE COURSE OF SENSORY CANALS. THE RIGHT-HAND LIMB ANASTOMOSES WITH THE SUBORBITAL. 
museums serving the coastal area are in extremely poor circumstances, and generally have only a director or curator, who cannot possibly be an expert in all branches of natural history. There are not uncommon fishes in the sea which to any of the latter would appear as strange as, if not stranger than, a coelacanthid. It was the energy and determination of Miss Latimer which saved so much, and scientific workers have good cause to be grateful. The genus Latimeria stands as my tribute.

\section{Science at the Royal Academy, I939}

$\mathrm{T}$

HE one hundred and seventy-first exhibition of the Royal Academy of Arts, which opened on May 1, may be described as conservative artistically, although many will regard it as dull. Whatever trends in art it may reveal, it is remarkable in that it reflects nothing of the alarms and excursions, of political events almost unparalleled, of the clash of arms and the clatter of armoured vehicles that dominated the period in which the painting was done. In the exhibition there are more Elizabethan men-at-arms on one picture than there are modern soldiers in the thousand other works. There is one interior that contains a gasmask, and, surprisingly, only two or three pictures of refugees.

Few will grieve at this eclipse of war even if only on canvas; but the neglect of belligerent science extends also to the other branches almost as much, and, of the thirteen hundred pictures on show, only about one hundred can be said to include any features of scientific interest and that even in the widest possible sense. Of the nine or ten branches of science which one may allege to be represented, botany and geology appear to be the most favoured.

Agriculture is fortunate in being depicted in two of the finest works in the Academy. "Harvest", by Dame Laura Knight, R.A., with its sunchequered scene, and James Bateman's "Haytime in the Cotswolds", one of the pleasantest landscapes of the year.

Antiquaries have not far to seek for interest, because the second picture in the first room is "Antiquity", by Alan Beeton, A.R.A. This shows a human skull surrounded by palæoliths and resting upon a copy of Antiquity. The work is rather small, but this is compensated by the very large panel, destined for Brighton Grammar School, entitled "Hollingbury Camp, 1929", by Louis Ginnett, in which a party of archæologists is seen at work in the field. The anthropologists are better served, numerically, with a dozen pictures of much interest and considerable artistic distinction. Dame Laura Knight again heads the list with "Gipsy Family", a typically brilliant study which is certain to be acclaimed as one of the pictures of the year. Negro studies are unusually prominent, of which "The Dance, Zululand" (218), "Zulu Woman" (271) and "Zulu Exodus" (278) should be mentioned. A. R. Thomson's "Prince Kessie of Ashanti" and Neville Lewis's "Pondo Youth" are interesting portraits. A more comprehensive work is "The Village in the Jungle", by David Paynter, with a man, a woman and a child in the foreground. In addition there are a study of a Jamaican, Japanese and Chinese portraits, and the delightful Burmese "Ma Seyn Nu", by Gerald Kelly, R.A.

For the botanists, there are a profusion of titles and a riot of colour. Apple blossom, carnations, celery, cinerarias, chrysanthemums, gladioli, lilies, marguerites, roses, tulips and even tobacco flowers (these last by Dod Procter) are only a selection of the delights available. There are also surprises, such as the unexpected "Ilex Tree", a Montallegro landscape by Gerald Kelly. Gilbert Spencer's "Cherry Tree in Winter" and Sallis Benney's "Beech Trees" are other arboreal attractions. There are flowers under their own names, flowers as "Still Life", "Rainbow Colours", "Purity", or just "Flowers". Mr. C. R. W. Nevinson's "Autumn bouquet", and Sir George Clausen's "Roses" are noteworthy, while Miss Grace English contributes a charming variety of colour contrasts in her "Summer Flowers".

Perhaps the most attractive of what may be termed the botanical works is Charles Oppenheimer's "Galloway Woodlands in February". This is a large picture with a background of typical rolling Galloway scenery. The woodland, the picture's main feature, is carpeted with snowdrops and the whole effect makes a charming picture one would like to possess.

Botanical and geological interests are combined in Malcolm Milne's "Val Fleuri", where the gay alpine flowers decorate the high valley. The other pictures which may interest the geologist cover various aspects of the science. Antony Ayrton's "Alpine Landscape" and Hilda Carline's "A Welsh Farm" illustrate a variety of mountain scenery 